\title{
The Impact of Combining Communicative Traits of Writing with Cooperative Learning on Trainee Teachers' Pedagogical Knowledge and Attitudes
}

\author{
Abdelaziz M. Hussien \\ Asst. Prof., Bahrain Teachers College, University of Bahrain, Sakheer, Bahrain; Faculty \\ of Education, Suez Canal University, Ismailia, Egypt, ahussien@uob.edu.bh
}

$\mid$

This article reports an investigation into the impact of presenting communicative traits of writing through cooperative learning on trainee teachers' pedagogical knowledge and attitudes towards a 'traits of writing' approach and cooperative learning. Mixed methodologies were used with the participants in a quasiexperimental repeated measure. Forty-two trainee teachers, enrolled in the Bahrain Teachers College, answered the pre and post pedagogical knowledge test and completed the two attitude scales at the end of semester. The results suggest that presenting communicative traits of writing through cooperative learning has a positive effect on the participants' pedagogical knowledge, and also has a positive impact on their attitudes towards communicative traits of writing approach, and attitudes towards cooperative learning. Further implications for teacher education are presented.

Keywords: communicative traits of writing, cooperative learning, pedagogical knowledge, attitudes, writing instruction

\section{INTRODUCTION}

Broadly speaking, emergent literacy level (Grades K-3) focuses on learning to write, while adolescent literacy level (Grades 4-12) emphasizes writing to learn. Writing is a key predictor of both academic achievement in territory education and success in a number of occupations in the workplace (Graham \& Perin, 2007; Sedita, 2013). The assumption is that students graduated from secondary school are competent writers and thus, higher education puts more emphasis on academic writing and writing as a means to meet study demands e.g. projects, reports, assessments, and research. The issue becomes more complicated in teacher education where trainee teachers are responsible for teaching writing in schools. Trainee teachers should know what writing involves, what quality writing looks like, and what empowers good writers. It is problematic when trainee teachers are lack of pedagogical knowledge about writing and the skills to use

Citation: Hussien, A. M. (2020). The Impact of Combining Communicative Traits of Writing with Cooperative Learning on Trainee Teachers' Pedagogical Knowledge and Attitudes. International Journal of Instruction, 13(1), 813-930. https://doi.org/10.29333/iji.2020.13152a 
this knowledge in their teaching, a lack which presumably negatively affects their teaching, learning, and assessing of writing.

In the current context, Bahraini trainee teachers have a traditional concept of writing as a product that mainly focuses on conventions, and organization in a form of a beginning, middle, and an end paragraph (Hussien, 2018). Many studies have been conducted to study Arabic writing in tertiary education. Previous research focused on trainee teachers' writing achievement and skills (Allamnakarah, 2017; Al Samman, 2014; Dkhikh, 2010). Previous studies were concerned with effective strategies and techniques in developing participants own writing skills. Furthermore, previous research was not concerned to develop a framework which would increase future teachers' knowledge about and skills in teaching writing in schools. These results show a lack of pedagogical knowledge of what quality writing looks like and what enables good writers, and also a lack of clarity and transparency in teaching, learning, and assessing of writing among trainee teachers. Establishing a framework of reference is one of the most important approaches that guides and facilitates teaching, learning, and assessing languages (Council of Europe, 2018). A 'traits of writing' model (Culham, 2003, 2010, 2015) and a 'communicative traits' model (Hussien, 2018) represent a framework for teaching, learning, and assessing of writing. This study is intended to investigate the effectiveness of combining communicative traits model with cooperative learning on trainee teachers' pedagogical knowledge, and attitudes. The hypothesis is that using communicative traits of writing through cooperative learning will improve trainee teachers' knowledge and skills for teaching quality writing to their pupils.

\section{Communicative Traits Model}

As stated earlier, establishing a framework of reference is one of the most important approaches that guides and facilitates teaching, learning, and assessing of languages (Council of Europe, 2018). It creates a shared vocabulary among interested people e.g., teachers, students, curriculum developers, or policy makers, with respect to teaching, learning and assessing of listening, reading, speaking and writing (Hussien, 2018). This common language creates a consistent understanding and serves as a baseline for teaching, learning, or assessing of writing (Culham, 2010, 2005, 2015). It can be argued that this shared vocabulary not only guides and facilitates teaching, learning and assessing of writing, but also characterizes how quality writing looks like. Culham $(2010,2005,2015)$ introduced the traits of a writing model that proposes seven traits (i.e. ideas, organization, voice, word choice, sentence fluency, conventions, and presentation). These traits characterize quality writing and enable good writers. She extensively explained how this traits and their characteristics motivate and shape quality teaching, learning and assessing of writing and enable good writers from pre-school through middle school level.

Creating a shared understanding of what good writing looks like is associated with Culhum (2005. 2010, 2015). The burgeoning interest in traits dated back to the mid1980s in America and was inspired by the work done by Pual Diederich (1974) on measuring growth in English. A group of teachers from different regions e.g., Oregon and Montana, closely analyzed reams of students' writings in order to create a reliable 
and concrete tool to measure writing performance. They classified students' writings into three categories: good, fair, and poor and identified the characteristics that were common to all pieces. This work led to an analytic assessment model and resulted in identifying seven traits of quality writing, mentioned above (Culham, 2005, p. 17; DeJarnette, 2008, p. 4). In contrast to a holistic (i.e., a single score model) this analytic assessment model (i.e., breaking the writing down into traits) helps us to develop a shared understanding of what good writing looks like and to develop good writers. This analytic assessment model helps us to establish meaningful, consistent, and accurate assessment and feedback about students' writing. Above all, it provides bases for the alignment of assessment with instruction (Culham, 2005, p. 16). In addition, the 'traits of writing' model is a process-centered approach where traits can be interwoven into the writing process which is the key to using traits effectively (Culham, 2003, p. 21).

In the early 1990s and after, researchers investigated the effectiveness of the traits of writing model. Arter, Spandel, Culham and Pollard (1994) pointed out that student scores improved on traits in proportion to the amount of time spent on them and the order in which they were introduced. The results of a large scale five year study with fifth grade teachers and students in 74 Oregon schools in Portland revealed that using traits of writing as an analytical approach is effective in improving students' writing with special reference to the traits of organization, voice and word choice (Coe, Hanita, Nishioka, \& Smiley, 2011). In another large-scale study, Coe (2000) pointed out the importance of using the traits of writing as strong predictors of passing the Washington Assessment of Student Learning test in writing. Results indicated that the traits of ideas, conventions and sentence fluency were more accurate predictors than were organization, word choice, and voice.

Inspired by Culham's model, the researcher (2018) developed a 'communicative traits' model (CTM) for Arabic. He identified seven communicative traits for each of the four language skills: writing, speaking, reading, and listening. CTM interweaves these traits with language skills in a communicative design and so productive writing and speaking traits are similar with some distinctions (i.e. ideas, organization, voice, word choice, sentence fluency, conventions, and presentation) and receptive reading and listening traits are similar with some distinctions (i.e. sounds and letters, vocabulary, comprehension, voice, fluency, meta-process, and habits). This CTM has been perceived by trainee teachers as an important framework that guides and makes teaching, learning and assessing of Arabic more focused, practical and evident. It might help better communications among professionals and decreased the lack of clarity and transparency among interested people in Arabic as a language used in numerous education contexts and systems (Hussien, 2018). This positive perception of the CTM needs to be tested further. The current study is pursued to investigate the effectiveness of this model with respect to writing to improve trainee teachers' pedagogical knowledge and attitudes for teaching quality writing to their pupils.

\section{Cooperative Learning}

The burgeoning interest in cooperative learning (CL) has existed since the 1980s and on into the 1990s (Gillies, 2016, p. 39), and was mostly associated with and investigated by 
Johnson and Johnson (1990, 1992, 1998, 2002, 2009) who defined CL as the instructional use of small groups of two or more students who work together to achieve the highest levels and maximize their own and each other's learning. It can be argued that working in structured small groups is the heart of cooperative learning (Millis, 2010 , p. 5). CL occurs through assigning students to work together in small groups formally, that can last from one class period to several weeks, informally, that can last from a few minutes to one class period, and cooperative based groups, that are longterm, heterogenous groups with stable membership (Johnson \& Johnson, 1998).

In contrast to competitive learning (i.e., students compete to achieve goals) and individualistic learning (i.e., students work individually), a meta-analysis research of 122 studies has shown that cooperative learning (i.e., students work together to achieve goals) was more effective across all subject areas, for all age groups, and for all tasks involved (Johnson, Maruyama, Johnson, Nelson, \& Skon, 1981). "Cooperative learning is widely recognized as a pedagogical practice that promotes socialization and learning among students from pre-school through to tertiary level and across different subject domains" (Gillies, 2016, p. 39). In the same vein, a meta-analysis research of 117 studies on learning together and alone by Johnson and Johnson (2002) emphasized the positive effects of CL on a range of academic and social variables from pre-school through higher education and adulthood e.g., achievement, social support, self-esteem, and interpersonal attraction. In a recent meta-analysis research, Johnson, Johnson, Roseth and Shin (2014) pointed that cooperative situations resulted in greater motivation and achievement than did competitive and individualistic situations. "Cooperation tends to promote the highest achievement, most positive relationships, and greatest psychological health" (Johnson, Johnson \& Holubec, 1984, p. 16)

Assigning students to groups does not necessarily promote cooperation, unless five components are established: positive interdependence, individual accountability, promotive interaction, social group skills, and group processing (Johnson \& Johnson, 1990, 2002; Johnson, Johnson \& Holubec, 1984). Teachers are required to plan and structure small groups in a way that all group members understand that they are linked together and no one can succeed unless they all do. Group members are willing to cooperate and help each other's learning to achieve the group goals and every single student has a contribution and a role to play to promote the group success (Gillies, 2016). Above all, teachers should train students on social skills (Johnson \& Johnson, 2009) e.g., how to manage disagreements, how to actively listen to each other or how to provide constructive comments to other's ideas. A final component, that teachers should consider when using small group work, is 'group processing' where the teacher teaches and discusses students how to model and reflect on their work and relationships e.g., what have we accomplished and what do we still need to achieve? These group processing discussions have positive effects on students achievements (Alexander, 2008; Johnson, Johnson, Stanne, \& Garibaldi, 1990).

Meta-analysis research (Lou, Abrami, \& d'Apollonia, 2001; Lou et al., 1996; Lou, Bernard, \& Abrami, 2006) indicates the importance of the group composition factor as students are likely to achieve more when they work together in heterogenous small 
groups of four or less students than in competitive or individualistic situations. Students assigned to different types of small groups are expected to interact face to face in the classroom and this interaction secures smooth communication, promotes interpersonal relationships, and improve group processing (Gillies, 2008; Graves \& Graves, 1985; Johnson \& Johnson, 2009). It also creates opportunities to exchange information, deepen understanding of materials, solve problems, and support one another in more effective and efficient manner (Johnson \& Johnson, 1996). In a nutshell, it "is a highly structured form of group work that focuses on the problem solving that ... can lead to deep learning, critical thinking, and genuine paradigm shifts in students' thinking" (Millis, 2010, p. 5). The purpose of this research was, therefore, to combine the CTM with a methodology based on the theory of cooperative learning to investigate the question of "what is the effectiveness of combining communicative traits of writing with cooperative learning on trainee teachers' pedagogical knowledge and attitudes?

\section{Context of the Study}

This research was carried out in a Bahraini context with trainee teachers from the Bahrain Teachers College (BTC) at University of Bahrain. BTC is a bilingual institution (i.e., Arabic and English) where all courses are taught in English except courses offered by the Arabic and Islamic Studies Department. 'Teaching Arabic Literacy for Young learners' (TC1ART363) is a teaching methods course offered by the Arabic department where the medium of instruction of this course is Arabic. The purpose of this research is to investigate into the effectiveness of combining communicative traits of writing with cooperative learning to deliver the above teaching methods course. This Arabic teaching methods course is a 3-credit hours throughout a 15 week term. The course is intended to develop trainee teachers' competencies in teaching Arabic focusing on writing and speaking skills to cycle one child (Grades 1-3) in Bahrain.

\section{Research Questions}

The current research sought answers of the following questions:

What is the effectiveness of combining communicative traits of writing with cooperative learning on trainee teachers' pedagogical knowledge?

What is the impact of combining communicative traits of writing with cooperative learning on trainee teachers' attitudes towards this type of learning approach?

What is the impact of combining communicative traits of writing on trainee teachers' attitudes towards cooperative learning?

What are trainee teachers' views on combining communicative traits of writing with cooperative learning approach?

\section{METHOD}

\section{Design}

Mixed methodologies were used with the participants in a quasi-experimental repeated measure (Cohen, Manion, \& Morrison, 2018). Forty-two class trainee teachers, enrolled in the Bahrain Teachers College, completed the pre and post author-developed 
pedagogical knowledge test. Also, two measures were used to survey the participants' attitudes towards the communicative traits of writing, and cooperative learning.

\section{Participants}

The researcher selected a purposeful sample. This sample consisted of 42 Bahraini trainee teachers ( 31 female and 11 male). The participants were enrolled in a third-year as 'class teachers' at BTC with an average age of 21 year old. BTC has two streams; specialized stream (Arabic, English, and Science) and class teacher stream. Class teachers teach core subjects i.e. Arabic, English, and Mathematics for primary school children (Grades 1-3) in Bahrain. Specialized teachers teach a specific subject (Arabic, English, mathematics, or science) for primary school children (Grades 4-6) in Bahrain. Written approval was obtained from the University of Bahrain research committee and oral consent from the participants. The participants had the chance to study the communicative traits' model, as the researcher taught class trainee teachers a course entitled 'Teaching Arabic Literacy for Young Learners, TC1ART363' in the second semester in 2018.

\section{Instruments}

To answer the research questions, the current study used mixed quantitative and qualitative research methods (Bryman, 2004). The researcher developed and administered four instruments in Arabic: a writing pedagogical knowledge test (WPKT); communicative traits attitude scale (CTAS); cooperative learning attitude scale (CLAS), and end of course reflective accounts. These instruments represent the dependent variables in the current study whereas the combining communicative traits of writing with cooperative learning was the independent variable of the study. To establish content validity (Cohen, Manion, \& Morrison, 2018), a panel of professors from BTC reviewed the instruments to ensure clarity and make sure the instruments are well representatives of the given constructs and topics of interest. Some amendments were suggested by the panel e.g., rewording some questions, and merging or deleting other questions that seemed repetitive. The instruments were approved and reported by the panel as valid, clear and appropriate to be employed. To establish reliability, all instruments were piloted, except the open-ended questions (end of course reflective accounts), with a group of 23 class trainee teachers in the previous cohort, other than the participants. Internal consistency were obtained as Cronbach's Alpha for WPKT, CTAS, and CLAS, $\alpha=0.81, \alpha=0.91, \alpha=0.90$, respectfully which are acceptable and reliable (Loewenthal, 2004).

\section{Writing pedagogical knowledge test}

The researcher developed the Writing Pedagogical Knowledge Test (WPKT). It is composed of 40 multiple choice questions to assess the trainee teachers' knowledge and understanding of the seven communicative traits of writing (i.e., ideas, organization, voice, word choice, sentence fluency, conventions, and presentation). Every four questions address a communicative trait of writing (28 question in total) e.g., the first four questions assess the trainee teachers' knowledge and understanding of ideas. Twelve questions address general knowledge related to the communicative traits 
approach. The trainee teachers completed the WPKT as pre and post-tests in a paper and pencil format. The trainee teachers' total scores can range from zero to 48. Data was analyzed using the paired samples $t$ test (SPSS 20) to compare between the participants' scores in the pre and posttests of WPKT.

\section{Communicative traits attitude scale}

Upon perusal of literature review on research related to attitudes to writing, the author developed a communicative traits attitude scale. The scale is composed of 27 items using a five-point Likert type scale, where participants are requested to rank items according to their level of agreement ranging from strongly agree to strongly disagree. The CTAS was administered to trainee teachers at the end of semester in a paper and pencil format. The trainee teachers' total scores can range from 27 to 135 . A descriptive analysis was used to analyze data derived from the CTAS.

\section{Cooperative learning attitude scale}

Literature review on group work and cooperative learning (e.g., Brame \& Biel, 2015; El-Deghaidy \& Nouby, 2008; Lu \& Argyle, 1991; Neo, 2004) inspired the researcher to construct this measure. CLAS is composed of 20 items using a five-point Likert type scale, where the participants are requested to rank items according to their level of agreement ranging from strongly agree to strongly disagree. CLAS was administered to trainee teachers at the end of semester and the total scores can range from 20 to 100. A descriptive analysis was used to analyze data derived from the CLAS.

\section{End of course reflective accounts}

As a requirement of studying the course 'Teaching Arabic Literacy for Young Learners, TC1ART363', each student is required to write an individual reflective account. The participants wrote reflective accounts about using the communicative traits of writing with cooperative as a teaching and learning approach to writing in this course. This can be related to and triangulated with (Bryman, 2004) data derived from both communicative traits and cooperative learning scales. These accounts were guided by these questions: 'What are the advantages of combining communicative traits of writing with cooperative learning in the teaching of writing?' 'What are the disadvantages of combining communicative traits of writing with cooperative learning in the teaching of writing?' 'What are your suggestions to improving this approach of learning? 'Would you use this approach with your classes? Why?' A cross-sectional code and retrieve method were used to categorize, index and organize data derived from the reflective accounts in an accessible, and manageable way that enables comparisons or connections (Mason, 2002; Spencer, Ritchie \& O’Conner, 2003).

\section{Procedure}

This research followed a repeated measures design in which the researcher administered the WPKT at the beginning of the course, Then, he taught trainee teachers this course. Students were assigned randomly to formal groups of four to work together throughout studying this course in the second semester in 2018. On the one hand, the researcher discussed the concept and characteristics of a trait with students and then modelled to 
students on how to design teaching and learning activities and to create rubrics to assess children's writings given the characteristics of a specific trait. On the other hand, trainee teachers were asked, in groups, to create, design, and present activities to teach this trait to children in the class. Trainee teachers were also requested, given characteristics of the trait, to develop a rubric to assess children's writing and then use this rubric to analyze and assess samples of children's writings in the class. At the end of the course, the researcher re-administered the WPKT. To survey the participants' attitudes and views on combining communicative traits of writing with cooperative learning approach, the researcher administered, at the end of the semester, both the communicative traits of writing scale and cooperative learning scale and then, asked students to write their reflective accounts.

\section{FINDINGS}

A paired-samples $t$ test was used to answer the first question, 'What is the effectiveness of combining communicative traits of writing with cooperative learning on trainee teachers' pedagogical knowledge?' as explained in Table 1.

Table 1

A Paired-Samples T Test Analysis of the Pre and Post Writing Pedagogical Knowledge Test $\mathrm{n}=42$

\begin{tabular}{|c|c|c|c|c|c|c|}
\hline Variables & Type of test & $M$ & $S D$ & $\mathrm{~T}$ & Sig. & $d$ \\
\hline \multirow[t]{2}{*}{ Ideas } & Pre & 3.71 & 0.95 & \multirow[t]{2}{*}{7.114} & \multirow[t]{2}{*}{0.000} & \multirow[t]{2}{*}{1.153} \\
\hline & Post & 5.30 & 0.93 & & & \\
\hline \multirow[t]{2}{*}{ Organization } & Pre & 3.31 & 0.81 & \multirow{2}{*}{15.308} & \multirow[t]{2}{*}{0.000} & \multirow[t]{2}{*}{2.500} \\
\hline & Post & 5.80 & 0.56 & & & \\
\hline \multirow[t]{2}{*}{ Voice } & Pre & 2.30 & 1.07 & \multirow[t]{2}{*}{8.846} & \multirow[t]{2}{*}{0.000} & \multirow[t]{2}{*}{1.435} \\
\hline & Post & 4.70 & 1.11 & & & \\
\hline \multirow[t]{2}{*}{ Word choice } & Pre & 3.11 & 1.29 & \multirow[t]{2}{*}{8.995} & \multirow[t]{2}{*}{0.000} & \multirow[t]{2}{*}{$1.45 \mathrm{C}$} \\
\hline & Post & 5.11 & 0.88 & & & \\
\hline \multirow[t]{2}{*}{ Sentence fluency } & Pre & 4.30 & 1.06 & \multirow[t]{2}{*}{8.504} & \multirow[t]{2}{*}{0.000} & \multirow[t]{2}{*}{1.379} \\
\hline & Post & 5.71 & 0.55 & & & \\
\hline \multirow[t]{2}{*}{ Conventions } & Pre & 2.82 & 0.94 & \multirow[t]{2}{*}{13.620} & \multirow[t]{2}{*}{0.000} & \multirow[t]{2}{*}{2.000} \\
\hline & Post & 5.33 & 0.80 & & & \\
\hline \multirow[t]{2}{*}{ Presentation } & Pre & 2.71 & 0.88 & \multirow[t]{2}{*}{12.871} & \multirow[t]{2}{*}{0.000} & \multirow[t]{2}{*}{2.089} \\
\hline & Post & 5.12 & 0.80 & & & \\
\hline \multirow[t]{2}{*}{ General knowledge } & Pre & 7.13 & 1.50 & \multirow[t]{2}{*}{12.578} & \multirow[t]{2}{*}{0.000} & \multirow[t]{2}{*}{2.041} \\
\hline & Post & 10.50 & 1.40 & & & \\
\hline \multirow[t]{2}{*}{ Total } & Pre & 29.51 & 3.40 & \multirow[t]{2}{*}{26.237} & \multirow[t]{2}{*}{0.000} & \multirow[t]{2}{*}{4.256} \\
\hline & Post & 47.55 & 3.44 & & & \\
\hline
\end{tabular}

Note: $\mathrm{p}<.01$.

Table 1 shows that there are significant differences between the pre $(\mathrm{M}=29.51, \mathrm{SD}=$ $3.40)$ and post $(\mathrm{M}=47.55, \mathrm{SD}=3.44)$ writing pedagogical knowledge test scores, $\mathrm{t}(41)$ $=26.237, \mathrm{p}<0.000, d=4.256$. Combining the communicative traits of writing with cooperative learning is strongly effective in writing pedagogical knowledge as a whole, and in each trait of writing as Cohen's $d$ reveals (Cohen, Manion, $\&$ Morrison, 2018, p. 746), in Table 1. 
To answer the second question, 'What is the impact of combining communicative traits of writing with cooperative learning on trainee teachers' attitudes towards this type of learning approach?', a descriptive analysis was used as depicted in table 2 below.

Table 2

Attitudes towards Communicative Traits of Writing as Ranked by Agreement, $\mathrm{N}=40$

\begin{tabular}{|c|c|c|c|c|}
\hline No. & Statements & $\begin{array}{l}\text { Positive } \\
\text { responses } \\
\text { (Percent) }\end{array}$ & $\begin{array}{l}\text { Neutral } \\
\text { responses } \\
\text { (Percent) }\end{array}$ & $\begin{array}{l}\text { Negative } \\
\text { response } \\
\text { (Percent) }\end{array}$ \\
\hline 1 & $\begin{array}{l}\text { Traits model creates a shared vocabulary and a common } \\
\text { language in teaching, learning, and assessing of writing }\end{array}$ & $100 \%$ & $00 \%$ & $00 \%$ \\
\hline 2 & $\begin{array}{l}\text { Traits model provides a framework of what constitutes good } \\
\text { writing }\end{array}$ & $87.5 \%$ & $12.5 \%$ & $00 \%$ \\
\hline 3 & Traits model enables a good writer of Arabic. & $82.5 \%$ & $17.5 \%$ & $00 \%$ \\
\hline 4 & $\begin{array}{l}\text { Traits model provides a concrete framework for teaching, } \\
\text { learning, and assessing of writing }\end{array}$ & $97.5 \%$ & $2.5 \%$ & $00 \%$ \\
\hline 5 & I feel confident when I use traits model in teaching writing & $90 \%$ & $10 \%$ & $00 \%$ \\
\hline 6 & I get focused when I use traits model in teaching writing & $85 \%$ & $15 \%$ & $00 \%$ \\
\hline 7 & $\begin{array}{l}\text { Traits can be blended with the stages of writing process i.e., } \\
\text { pre-writing, writing, post-writing. }\end{array}$ & $85 \%$ & $15 \%$ & $00 \%$ \\
\hline 8 & Traits model is an important to teach writing in Arabic & $95 \%$ & $5 \%$ & $00 \%$ \\
\hline 9 & Traits model has a positive impact on learning of writing & $95 \%$ & $5 \%$ & $00 \%$ \\
\hline 10 & Traits can be used to teach writing throughout school education & $92.5 \%$ & $7.5 \%$ & $00 \%$ \\
\hline 11 & $\begin{array}{l}\text { Traits model serves as an important baseline to design teaching } \\
\text { and learning of writing }\end{array}$ & $85 \%$ & $15 \%$ & $00 \%$ \\
\hline 12 & $\begin{array}{l}\text { Traits model serves as an important baseline to design rubric } \\
\text { for assessing writing }\end{array}$ & $82.5 \%$ & $17.5 \%$ & $00 \%$ \\
\hline 13 & $\begin{array}{l}\text { Traits model can be used to teach all types of genres e.g., story, } \\
\text { letters, or essay. }\end{array}$ & $95 \%$ & $5 \%$ & $00 \%$ \\
\hline 14 & Traits model has a high benefit for writing instruction & $85 \%$ & $5 \%$ & $00 \%$ \\
\hline 15 & Traits model makes teaching and learning of writing easier & $90 \%$ & $7.5 \%$ & $2.5 \%$ \\
\hline 16 & $\begin{array}{l}\text { Traits model is a process-focused approach rather than a } \\
\text { product-centered one }\end{array}$ & $97.5 \%$ & $2.5 \%$ & $00 \%$ \\
\hline 17 & I feel confident learning necessary skills to using traits model & $85 \%$ & $12.5 \%$ & $2.5 \%$ \\
\hline 18 & I enjoy talking with others about traits model & $67.5 \%$ & $27.5 \%$ & $5 \%$ \\
\hline 19 & $\begin{array}{l}\text { I feel optimistic when I walk into a classroom knowing that I } \\
\text { will use traits model to teach writing }\end{array}$ & $82.5 \%$ & $15 \%$ & $2.5 \%$ \\
\hline 20 & $\begin{array}{l}\text { Traits model increases cooperation with peers in writing } \\
\text { instruction }\end{array}$ & $82.5 \%$ & $12.5 \%$ & $5 \%$ \\
\hline 21 & $\begin{array}{l}\text { Traits model in the classroom will help me become a better } \\
\text { teacher of writing }\end{array}$ & $97.5 \%$ & $2.5 \%$ & $00 \%$ \\
\hline 22 & $\begin{array}{l}\text { Language teacher education programmes should include how } \\
\text { to deal with traits model }\end{array}$ & $90 \%$ & $10 \%$ & $00 \%$ \\
\hline 23 & $\begin{array}{l}\text { I think learning Arabic literacy for young learners course via } \\
\text { traits model will help my future work }\end{array}$ & $97.5 \%$ & $2.5 \%$ & $00 \%$ \\
\hline 24 & $\begin{array}{l}\text { I want to learn Arabic literacy for young learners course via } \\
\text { traits model }\end{array}$ & $92.5 \%$ & $7.5 \%$ & $00 \%$ \\
\hline 25 & $\begin{array}{l}\text { I wait with passion for learning Arabic literacy for young } \\
\text { learners course via traits model }\end{array}$ & $82.5 \%$ & $15 \%$ & $2.5 \%$ \\
\hline 26 & $\begin{array}{l}\text { I enjoy learning Arabic literacy for young learners course via } \\
\text { traits model }\end{array}$ & $90 \%$ & $7.5 \%$ & $2.5 \%$ \\
\hline 27 & $\begin{array}{l}\text { I can learn Arabic literacy for young learners course better with } \\
\text { referring to traits model }\end{array}$ & $92.5 \%$ & $7.5 \%$ & $00 \%$ \\
\hline
\end{tabular}

International Journal of Instruction, January $2020 \bullet$ Vol.13, No.1 
Table 2 shows that all the participants agreed (item 1) on the importance of traits model in creating a shared vocabulary and a common language in teaching, learning, and assessing of writing. 39 out of 40 trainee teachers (item 4) think that this model provides a concrete framework for teaching, learning, and assessing of writing, and eventually, using the model in the classroom will help them to become better teachers of writing (97.5\%). Most responses are well above $80 \%$ percent of an agreement and most items got no negative responses. This result indicates very positive views on using traits of writing as framework to writing instruction.

In the same direction, a descriptive analysis was used to answer the third question, "What is the impact of combining communicative traits of writing on trainee teachers' attitudes towards cooperative learning?'

Table 3

Students' Attitudes towards Cooperative Learning as Ranked by Agreement, $\mathrm{N}=40$

\begin{tabular}{|c|c|c|c|c|}
\hline No. & Statement & $\begin{array}{l}\text { Positive } \\
\text { responses } \\
\text { (Percent) }\end{array}$ & $\begin{array}{l}\text { Neutral } \\
\text { response } \\
\text { (Percent) }\end{array}$ & $\begin{array}{l}\text { Negative } \\
\text { responses } \\
\text { (Percent) }\end{array}$ \\
\hline 1 & $\begin{array}{l}\text { A small group learning is an important approach to } \\
\text { writing instruction }\end{array}$ & $95 \%$ & $5 \%$ & $00 \%$ \\
\hline 2 & $\begin{array}{l}\text { A small group learning is the best way to teach } \\
\text { children in school }\end{array}$ & $72 \%$ & $20 \%$ & $8 \%$ \\
\hline 3 & I share my ideas or materials with group-mates & $97 \%$ & $3 \%$ & $00 \%$ \\
\hline 4 & $\begin{array}{l}\text { I like to cooperate with other students over academic } \\
\text { work }\end{array}$ & $87 \%$ & $10 \%$ & $3 \%$ \\
\hline 5 & $\begin{array}{l}\text { It is often easy working together with other group- } \\
\text { mates }\end{array}$ & $54 \%$ & $28 \%$ & $18 \%$ \\
\hline 6 & I feel satisfied to be involved in small group projects & $77 \%$ & $20 \%$ & $3 \%$ \\
\hline 7 & $\begin{array}{l}\text { It is often more productive to work in small group } \\
\text { projects }\end{array}$ & $67 \%$ & $25 \%$ & $8 \%$ \\
\hline 8 & $\begin{array}{l}\text { A small group learning is always the best way of } \\
\text { getting good results }\end{array}$ & $44 \%$ & $33 \%$ & $23 \%$ \\
\hline 9 & $\begin{array}{l}\text { It is easy to arrive at an agreed decision in small } \\
\text { groups }\end{array}$ & $52 \%$ & $28 \%$ & $20 \%$ \\
\hline 10 & Working as a team member helps in future work & $92 \%$ & $8 \%$ & $00 \%$ \\
\hline 11 & $\begin{array}{l}\text { Decisions taken by small groups are better than } \\
\text { those taken by individuals }\end{array}$ & $69 \%$ & $26 \%$ & $5 \%$ \\
\hline 12 & $\begin{array}{l}\text { Cooperation between members of the team is the key } \\
\text { to success }\end{array}$ & $87 \%$ & $10 \%$ & $3 \%$ \\
\hline 13 & $\begin{array}{l}\text { Work accomplished in small groups has more } \\
\text { quality than that accomplished individually }\end{array}$ & $59 \%$ & $28 \%$ & $13 \%$ \\
\hline 14 & $\begin{array}{l}\text { Participating in small group learning helps exchange } \\
\text { experiences }\end{array}$ & $92 \%$ & $8 \%$ & $00 \%$ \\
\hline 15 & $\begin{array}{l}\text { Working in small groups develops friendships with } \\
\text { other students }\end{array}$ & $87 \%$ & $10 \%$ & $3 \%$ \\
\hline 16 & $\begin{array}{l}\text { Participating in a small group learning increases } \\
\text { motivation to work }\end{array}$ & $75 \%$ & $20 \%$ & $5 \%$ \\
\hline 17 & I learn more from in small group than on my own & $67 \%$ & $23 \%$ & $10 \%$ \\
\hline 18 & A small group work makes learning easier & $64 \%$ & $28 \%$ & $8 \%$ \\
\hline 19 & A small group work improves quality of learning & $75 \%$ & $20 \%$ & $5 \%$ \\
\hline 20 & $\begin{array}{l}\text { Working in a small group improves my } \\
\text { understanding of a task in question than on my own }\end{array}$ & $87 \%$ & $13 \%$ & $00 \%$ \\
\hline
\end{tabular}


As explained in Table 3 above, the participants showed a very positive response towards cooperative learning as a method to writing instruction (item 1) and to improving future work in schools (item 10). Although the trainee teachers are willing to cooperate and share ideas or materials with their group-mates (item 3), they responded less positively on items related to challenges (items $5,8,9$ ) they face when participating in cooperative learning.

Regarding the fourth and last question, 'What are trainee teachers' views on combining communicative traits of writing with cooperative learning approach? The feedback received from students, in a form of written reflective accounts, on using the communicative traits through cooperative learning was strongly positive and encouraging. Thematizing and categorizing students' responses (Bryman, 2004) revealed strong support for the use of communicative traits through cooperative learning as an effective approach in writing instruction (35) suggesting it's reach to other language processes, speaking, reading, listening (15). Two aspects seemed to have been valued most by trainee teachers in this approach; using a shared vocabulary that guides teaching, learning, and assessing of writing (25) and the practicality of this approach in designing teaching and learning activities and in creating rubrics for assessing children's writings (18). Above all, working in small groups to design activities or rubrics was beneficial as it helped clear challenges and support for the quality of their work (14). Limited disadvantage responses related to challenges in the reality were reported (7).

Positive written responses to the question on the advantages of using communicative traits through cooperative learning?' emphasized its significance in creating a shared and concrete vocabulary in writing instruction, 'I have a clear vision on how to design and develop interesting and joyful activities to teach writing to children using the seven traits of writing'. Participants also valued working in groups, 'members of groups have the opportunity to learn from each other and share important ideas either in teaching or assessing of writing'. Negative responses to the question on the disadvantages of using communicative traits through cooperative learning ?' refereed to the time and effort needed to handle the analytical assessment, 'when it comes to assessment, it is exhausted to use all traits and characteristics to assess students' writing'. In addition, they expressed their fear of disconnection between what they study and school reality, 'in reality when we go to practicum we find no existence of traits of writing approach in schools and hence what we learn is limited to the college building'

Trainee teachers offered important suggestions to improve this approach of learning. They explained that, 'it is important to utilize different techniques e.g., videos, and outdoor activities. Children can go outside classroom and watch the front of school building and how it looks like and then teachers can utilize this in teaching the trait of presentation and how the writing looks like on the page'. They claimed that the more time they spend the more quality teaching they expect, 'more time, that is what we need to practice and maintain the quality of teaching and assessing of writing using traits. Participants showed willingness to use this approach with their classes, 'definitely, I will use it because it makes teaching of writing more focused and assessing of writing more objective. I can precisely explain student's weaknesses and strengths and how to move 
forward in her writing'. Moreover, 'it provides a framework to either teaching or assessing of writing using a shared vocabulary and common language between teachers and students.

\section{DISCUSSION}

The aim of this study is to investigate the effectiveness of combining the communicative traits of writing with cooperative leaning (CTWCL) on developing Bahraini trainee teachers' writing pedagogical knowledge, attitudes to cooperative learning, and attitudes towards this type of approach to learning, and views on using this approach in writing instruction. Three significant findings of this study were reported.

The results of paired samples $t$ test (Table 1) emphasized that there were significant differences $(p<0.01)$ in trainee teachers' writing pedagogical knowledge scores $(40$ question) between pre and post measurements in a favor of the post test. The CTWCL approach was found to be strongly effective $(d=4.256)$ in writing pedagogical knowledge as a whole, and in each one of the seven traits: ideas, organization, voice, word choice, sentence fluency, conventions, and presentation. Above all, the same result was found pertaining to general knowledge of writing instruction (12 out of 40 question). Trainee teachers are expected to support students writing using this type of instruction in the future.

Although with some differences, the current results are consistent with results proved by Kozlow and Bellamy (2004). They explained that, as a result of the training in $6+1$ trait writing model, teachers developed pedagogical knowledge and skills for writing instruction and assessment to grades 4 to 6. Rietdijk, Janssen, Van Weijen, Van den Bergh, and Rijlaarsdam (2017) used a 'comprehensive writing program' combining communicative aspects of writing, writing process, and teaching of five genre-specific writing strategies to improve students' writing performance (Grades 4 to 6) and to influence in-service teachers' practice, beliefs, and skills for writing instruction. In the significant results of current study focused on trainee teacher's pedagogical knowledge and attitudes towards writing, while the previous research focused on writing achievement and skills (Allamnakarah, 2017; Al Samman, 2014; Dkhikh, 2010). The same direction, previous studies were concerned with undergraduates writing performance (Kuiper, Smit, De Wachter, \& Elen, 2017; Van der loo, Krahmer, \& Van Amelsvoort, 2018).

A plausible explanation of these significant and positive results is due to that combining communicative traits of writing with cooperative learning provides a framework to teaching, learning, and assessing of writing. This framework enhances trainee teachers' pedagogical knowledge by creating a concrete common language that can be used in a handy and practical way in writing instruction. Trainee teachers cooperated to use this shared vocabulary to teach and design activities and to develop rubrics and assess and analyze writing in a concrete and approachable way.

The results of this study showed that trainee teachers developed positive attitudes towards using the communicative traits of writing approach as explained in Table 2 above. The current results are consistent with results proved by Kozlow and Bellamy 
(2004, p. 49). They explained that, as a result of the training in $6+1$ trait writing model, teachers developed positive attitudes towards traits of writing model. Those teachers improved their overall skill in writing instruction and assessment, developed better understanding of the qualities of good writing, gave effective feedback to their students, communicated more effectively with parents about their children's writing, and helped students to develop more positive attitudes towards writing. Trainee teachers are expected to support students writing using this type of instruction in the future.

In the same vein, the current findings showed trainee teachers' positive attitudes towards cooperative learning. This result is congruent with previous research that found cooperative learning as a preferable learning approach by students (Brame \& Biel, 2015; El-Deghaidy \& Nouby, 2008; Lu \& Argyle, 1991; Neo, 2004). However, the participants showed less agreement on items related to challenges that they face in groups work as explained in Table 3 earlier e.g., (item 9) 'it is easy to arrive at an agreed decision in small groups. This emphasizes the importance of training students on how to deal with groups work challenges. Johnson and Johnson (2009) explained that teachers should train students on social skills e.g., how to manage disagreements, how to actively listen to each other or how to provide constructive comments to other's ideas.

Written responses feedback received from trainee teachers, in a form of reflective accounts, at the end of course revealed important advantages of combining the communicative traits of writing with cooperative learning approach. Responses were related to and triangulated (Bryman, 2004) with data derived from both the communicative traits attitude scale and cooperative learning attitude scale. Responses to item 1 (Table 2), 'traits model creates a shared vocabulary and a common language in teaching, learning, and assessing of writing, showed positive attitudes to the communicative traits model as 32 strongly agreed, and 8 agreed that this model helps in creating a shared vocabulary and a common language in teaching, learning, and assessing of writing. Responses to item 22 (Table 2), 'traits model in the classroom will help me become a better teacher of writing, revealed that the experience in this course will help trainee teachers to become better teachers in schools as 28 strongly agreed, 11 agreed, and 1 gave neutral response. Furthermore, responses to item 1 (Table 3), 'a small group learning is an important approach to writing instruction' indicated positive views of cooperative learning as a method to writing instruction in schools as 25 strongly agreed, 12 agreed, and 2 neutral response. This coincides with previous research that found cooperative learning as a preferable learning approach by students (Brame \& Biel, 2015; El-Deghaidy \& Nouby, 2008; Lu \& Argyle, 1991; Neo, 2004)

This positive results can be due to various reasons chief among them, communicative traits of writing through cooperative learning approach is a very organized and simple model that creates concrete shared vocabulary that guide teaching, learning, assessment of writing among concerned people e.g., teachers and students. It also offered participants the chance to design activities and develop rubrics in a practical and real way. Above all, it gave participants the opportunity to work cooperatively in either designing and presenting activities or developing rubrics and analyzing children's 
writings. All of this could have positively affected trainee teachers' views on using the communicative traits of writing through cooperative learning approach.

\section{CONCLUSION}

Given the results reported in this research, this study has important implications for teacher education, and contributes to and enhances the current literature related to communicative traits of writing, and cooperative learning. While previous research focused on traits of writing in improving writing achievement (e.g., Arter, Spandel, Culham, \& Pollard, 1994; Coe, 2000; Coe, Hanita, Nishioka, \& Smiley, 2011; Kozlow \& Bellamy, 2004), this study provides an empirical evidence on the effectiveness of using communicative traits of writing through cooperative learning in developing trainee teachers' pedagogical knowledge and attitudes towards writing instruction. The results revealed that this approach is significantly effective in improving trainee teachers' pedagogical knowledge and attitudes towards writing instruction. In addition, the present study introduced a framework to writing instruction in Arabic, whereas the previous studies focused on improving trainee teachers writing skills (e.g., Allamnakarah, 2017). Above all, the findings indicated that combining communicative traits with cooperative learning is a preferable approach by trainee teachers in teaching, learning, and assessing of writing. The current study used qualitative data, reflective accounts, that seem more appropriate to capture trainee teachers' cooperativeness and attitudes towards using communicative traits of writing. The participants showed very positive attitudes towards cooperativeness, and using communicative traits. To address limitations of the study, further research is required to compare between presenting communicative traits through cooperative, competitive or individualistic learning. Also, further research is needed to investigate the effect of using the communicative traits of writing with cooperative learning on trainee teachers writing skills.

\section{ACKNOWLEDGEMENT}

My sincere gratitude goes to professor Mike Byram, University of Durham, for his constant support and guidance.

\section{REFERENCES}

Abbott, M., Wills, H., Miller, A., \& Kaufman, J. (2012). The relationship of error rate and comprehension in second and third grade oral reading fluency. Reading Psychology, 33(1-2), 104-132. http://dx.doi.org/10.1080/02702711.2012.630613.

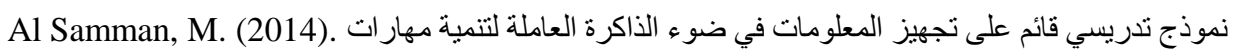
ن القر اءة للار اسة و الكتابة الأكاديمية لدى الطلاب معلمي اللغة العربية بكليات التربية on information processing in light of working memory to develop reading for study and academic writing for Arabic teachers candidates]. Studies in Curriculum and Instruction, 204, 51-97. http://search.mandumah.com/Record/715132

Alexander, A. (2008). Essays on pedagogy. London: Routledge

Allmanakhrah, A. (2017). فاعلية برنامج نمذجة كتابية في تنمية مهارات الكتابة لدى طلاب جامعة الملك فThe effectiveness of writing modeling program in the development of King 
Abdulaziz University student's writing skills]. Journal of Educational and Psychological Sciences, 2(18), 613-644. http://search.mandumah.com/Record/879411

Arter, J., Spandel, V., Culham, R., \& Polard, J. (1994). The impact of training students to be self-assessors of writing. Paper presented at the Annual Meeting of the American Educational Research Association. Orleans. https://files.eric.ed.gov/fulltext/ED370975.pdf

Brame, C. J., \& Biel, R. (2015). Setting up and facilitating group work: Using cooperative learning groups effectively. Retrieved from http://cft.vanderbilt.edu/guides-sub-pages/setting-up-and-facilitating-group-work-usingcooperative-learning-groups-effectively/.

Bryman, A. (2004). Social research methods. Oxford: Oxford University Press.

Coe, M. T. (2000). Direct writing assessment in action: Correspondence of six-trait writing assessment scores and performance on an analog to the Washington assessment of student learning writing test. Portland, OR: Northwest Regional Educational Laboratory.

Coe, M. T., Hanita, M., Nishioka, V., \& Smiley, R. (2011). An investigation of the impact of the 6+1 trait writing model on grade 5 student writing achievement, final report. U.S. Department of Education: Institute of Education Sciences. http://files.eric.ed.gov/fulltext/ED527445.pdf

Cohen, L., Manion, L., \& Morrison, K. (2018). Research methods in education. London: Routledge

Culham, R. (2003). 6+1 traits of writing: The complete guide, grades 3 and up. New York: Scholastic Inc.

Culham, R. (2005). 6+1 traits of writing: The complete guide for the primary grades. New York: Scholastic Inc.

Culham, R. (2015). Traits of writing: The complete guide for middle school. New York: Scholastic Inc.

Council of Europe (2018). Common European framework of reference for languages: Leaning, teaching, assessment: Companion volume with new descriptors. Retrieved from https://www.coe.int/en/web/common-european-framework-reference-languages.

DeJarnette, N. K. (2008). Effect of the 6+1 trait writing model on student writing achievement. Retrieved from http://citeseerx.ist.psu.edu/viewdoc/download?doi=10.1.1.833.2020\&rep=rep1\&type=p df.

Diedderich, P. (1974). Measuring growth in English. Urbana: National Council of Teachers of English.

Dkhikh, S. (2010). أثر وحدات تعليمية في تتمية مهارات الكتابة الوظيفية لدى طلاب كلية التربية في الباحة [The impact of instructional units in developing of functional writing skills among 
trainee teachers in Al - Baha]. Journal of Specific Education Research, 17, 156-192. http://search.mandumah.com/Record/65525.

El-Deghaidy, H., \& Nouby, A. (2008). Effectiveness of a blended e-learning cooperative approach in an Egyptian teacher education programme. Computers \& Education, 51(3), 988-1006. https://doi.org/10.1016/j.compedu.2007.10.001.

Graham, S., \& Perin, D. (2007). A meta-analysis of writing instruction for adolescent students. Journal of Educational Psychology, 99(3), 445-476. doi: 10.1037/00220663.99.3.445.

Graves, N., \& Graves, T. (1985). Creating a cooperative learning environment: An ecological approach. In R. Slavin, S. Sharan, S. Kagan, R. Lazarowitz, C. Webb, \& R. Schmuck (Eds.), Learning to cooperate, cooperating to learn (pp. 403-436). New York: Plenum.

Gillies, R. (2008). The effects of cooperative learning on junior high school students' behaviours, discourse, and learning during a science-based learning activity. School Psychology International, 29, 328-347. https://doi.org/10.1177/0143034308093673.

Gillies, R. (2016). Cooperative learning: Review of research and practice. Australian Journal of Teacher Education, 41(3), 39-54.doi: 10.14221/ajte.2016v41n3.3.

Hussien, A. M. (2018). Culture of traits in Arabic language education: Students' perception of the communicative traits model. International Journal of Instruction, 11(4), 467-484. https://doi.org/10.12973/iji.2018.11429a.

Johnson, D., \& Johnson, R. (1990). Cooperative learning and achievement. In S. Sharan (Ed.), Cooperative learning: Theory and research (pp. 23-37). New York: Praeger.

Johnson, D., \& Johnson, R. (1992). Positive interdependency: Key to effective cooperation. In R. Hertz-Lazarowitz \& N. Miller (Eds.), Interaction in cooperative groups: The theoretical anatomy of group learning (pp. 174-199). Cambridge: Cambridge University Press.

Johnson, D., \& Johnson, R. (1996). Cooperation and the use of technology. In D. Jonassen (Ed.), Handbook of research for educational communications and technology (pp. 1017-1044). New York: Macmillan.

Johnson, D., \& Johnson, R. (1998). Cooperative learning and social interdependence theory. In R. S. Tindale, L. Heath, J. Edwards, E. J. Posavac, \& F. B. Bryant (Eds.), Theory and research on small groups (pp. 9-35). New York: Plenum Press.

Johnson, D., \& Johnson, R. (2002). Learning together and alone: Overview and metaanalysis. Asia Pacific Journal of Education, 22(1), 95-105. https://doi.org/10.1080/0218879020220110.

Johnson, D., \& Johnson, R. (2009). An educational psychology success story: Social interdependence theory and cooperative learning. Educational Researcher, 38, 365 -379. https://doi.org/10.3102/0013189X09339057. 
Johnson, D., Johnson, R., \& Holubec, E. (1998). Cooperation in the classroom. Allyn and Bacon: Springer.

Johnson, D., Johnson, R., Roseth, C., \& Shin, T. (2014). The relationship between motivation and achievement in interdependent situations. Journal of Applied Social Psychology, 44(9), 622-633. http://dx.doi.org/10.1111/jasp.12280.

Johnson, D., Johnson, R., Stanne, M., \& Garibaldi, A. (1990). Impact of group processing on achievement in cooperative groups. Journal of Social Psychology, 130 (4), 507-516. https://doi.org/10.1080/00224545.1990.9924613.

Johnson, D., Maruyama, G., Johnson, R., Nelson, D., \& Skon, L. (1981). Effects of cooperative, competitive, and individualistic goal structures on achievement: A metaanalysis. Psychological Bulletin, 89(1), 47-62. http://dx.doi.org/10.1037/00332909.89.1.47.

Kozlow, M. \& Bellamy, P. (2004). Experimental study on the impact of the $6+1$ trait writing model on student achievement in writing. https://educationnorthwest.org/sites/default/files/resources/Student_Achievement_in_Wr iting.pdf .

Kuiper, C., Smit, J., De Wachter, L., \& Elen, J. (2017). Scaffolding tertiary students' writing in a genre-based writing intervention. Journal of Writing Research, 9(1), 27-59. doi: 10.17239/jowr-2017-09-01-02.

Loewenthal, K. M. (2004). An introduction to psychological tests and scales. Hove, UK: Psychology Press.

Lu, L., \& Argyle, M. (1991). Happiness and cooperation. Personality and Individual Differences, 12(10), 1019-1030. https://doi.org/10.1016/0191-8869(91)90032-7

Lou, Y., Abrami, P., Spence, J., Poulsen, C., Chambers, B., \& d'Apollonia, S. (1996). Within-class grouping: A meta-analysis. Review of Educational Research, 66(4), 423 458. https://doi.org/10.3102/00346543066004423.

Lou, Y., Abrami, P., \& d'Apollonia, S. (2001). Small group and individual learning with technology: A meta-analysis. Review of Educational Research, 71(3), 449-521. https://doi.org/10.3102/00346543071003449.

Lou, Y., Bernard, R., \& Abrami, P. (2006). Media and pedagogy in undergraduate distance education: A theory-based meta-analysis of empirical literature. Educational Technology Research and Development, 54(2), 141-176. https://www.jstor.org/stable/30221319.

Mason, J. (2002). Qualitative researching. London: SAGE

Millis, B. (Ed.) (2010). Cooperative learning in higher education. Virginia: Stylus publishing.

Neo, M. (2004.). Cooperative learning on the web: A group based, student centered learning experience in the Malaysian classroom. Australasian Journal of Educational 
Technology, 20 (2), 171-190. https://doi.org/10.14742/ajet.1358.

Rietdijk, S., Janssen, T., Van Weijen, D., Van den Bergh, H., \& Rijlaarsdam, G. (2017). Improving writing in primary schools through a comprehensive writing program. Journal of Writing research, 9(2), 173-225. doi: 10.17239/jowr-2017-09-02-04.

Sedita, J. (2013). Learning to write and writing to learn. In M. C., Hougen (Ed.), Fundamentals of literacy instruction \& assessment (pp. 6-12). Baltimore: Paul H. Brookes.

Spencer, L., Ritchie, J., \& O'Connor, W. (2003). Analysis: practices, principles and processes. In J. Ritchie and J. Lewis (Eds.), Qualitative research practice: A guide for social science students and researchers (pp. 199-218). London: SAGE.

Van der loo, J., Krahmer, E., \& Van Amelsvoort, M. (2018). Learning how to write an academic text: The effect of instructional method and writing preference on academic writing performance. Journal of Writing Research, 9(3), 233-258. doi: 10.17239/jowr2018.09.03.01. 